\title{
CREDIT PARTICIPATION AND CONSTRAINTS OF THE POOR IN PERI-URBAN AREAS, VIETNAM: A MICRO-ECONOMETRIC ANALYSIS OF A HOUSEHOLD SURVEY
}

This paper uses a dataset collected from peri-urban areas of Ho Chi Minh City, Vietnam to examine how the poor use their loans, and factors affecting their credit participation and credit constraints. The paper finds that the presence of many commercial banks in the areas does not help the poor, instead the poor rely heavily on informal credit. Loans in the periurban areas are mainly used for non-productive purposes, which stresses the importance of consumption smoothing. Better community relationships and interpersonal trust in morerural wards help households to access to credit. In urban areas, the poor rely more upon subsidized funds. A closer look at specified microcredit sources reveals that household behaviour differs in each market segment. Furthermore, the poor are highly credit-constrained. Wealthier-asset households among the poor appear to be less credit-constrained. The likelihood of credit constraints increases with the distance to the nearest banks, which suggests that credit supplyside intervention could help overcome credit constraints. Overall, the poor in urban areas are more credit-constrained because of exclusion by commercial banks and weaker interpersonal trust.

Keywords: Credit participation; credit constraints; the poor; peri-urban; Vietnam

JEL Classification: C24, C25, H81, R22

DOI: $10.15611 /$ aoe.2015.1.07

\section{INTRODUCTION}

Microfinance, including microcredit as the main part, and other micro financial services such as insurance and savings vehicles, has become a popular tool in poverty alleviation efforts in developing countries (Armendariz, Morduch, 2010). The poor have inadequate access to formal credit resources because of barriers imposed by lenders and the relatively high transaction costs for smallsize loans that discourage lending to the poor (Khandker, 2005; Pitt, Khandker, 1998). Thus, a sizeable proportion of poor households borrow from the informal credit sector (Banerjee, Duflo, 2010).

\footnotetext{
* Economics Department, the University of Waikato, Hamilton, New Zealand and Faculty of Political Economy, VNU University of Economics and Business, Hanoi, Vietnam ** Faculty of Political Economy, VNU University of Economics and Business, Hanoi, Vietnam
} 
In Vietnam, the poor typically fail to meet the formal credit requirements and hence find it difficult to obtain access to formal credit. Some studies show that the informal credit sector provided approximately $50 \%$ of the total credit to the poor and low income households (IFC, 2006; VDR, 2004).

The success of microcredit in alleviating poverty first depends on credit participation. The existing empirical evidence on the determinants of credit participation and credit constraints is well established for rural areas in developing countries (Barslund, Tarp, 2007; Nguyen, 2007; Izumida, Pham, 2002; Diagne, Zeller, Sharma, 2000; Diagne, 1999), and for more developed countries (e.g. Chen, Chivakul, 2008; Crook, 2001; Crook, Hochguertel, 2005; Crook, Hochguertel, 2007; Del-Rio, Young, 2005). In contrast, investigation into the determinants of credit participation and credit constraints for peri-urban households in Vietnam and elsewhere is rare.

The lack of analysis for peri-urban areas probably results from a belief that in the urban and peri-urban areas, financial facilities are handy and so financial services are available to everyone. This may not be true as the poor in developing countries who migrate to cities often dwell in peri-urban areas and usually rely upon credit to smooth their consumption expenditure. ${ }^{1}$ Unlike the rural poor who can increase labour earnings via off-farm work, reduce purchasing other inputs and use more self-produced products when they face negative shocks, the urban or peri-urban poor do not have the same coping strategies (Kochar, 1995). Most of the urban and peri-urban poor are unskilled and involved in informal economic sector activities. They are mainly casual workers (Rashid, 2000). However, during adverse shocks (e.g. disaster, economic), work opportunities and wages decrease, hence households are unable to offset the income decline by sending more members to labour markets or by increasing the number of working hours as do the poor in rural areas (McKenzie, 2004; Fallon, Lucas, 2002; Rashid, 2000). Therefore, to fill the income shortage, credit would become important in these areas, especially for the poor who have low savings (Skoufias, 2003).

Nevertheless, the determinants of credit participation and credit constraints for the poor in these areas remain unknown. This gap in the current literature prompts the current study to search for answers to the following questions: First, does the presence of financial institutions fully

\footnotetext{
${ }^{1}$ For example, data from HCMC Statistical Office show that population growth rates are $2.7 \%$ and $82 \%$ for urban districts and peri-urban districts over the last 12 years (1997-2009), respectively. These data are available at http://www.pso.hochiminhcity.gov.vn/so_lieu_ktxh/2000/ Dan_so_va_lao_dong/0203.htm/view, and http://www.pso.hochiminhcity.gov.vn/so_lieu_ $\mathrm{ktxh} / 2009 / \mathrm{Dan}$ _so_va_lao_dong/0201.htm/view
} 
offer the peri-urban poor access to credit resources? Second, what are the determinants of credit constraints and credit participation of the poor? Third, is the credit market segmented, even just amongst the poor, in the peri-urban areas? The paper is structured as follows: the next section discusses the data collection and analysis framework. The empirical results are presented in Section 3 . The final section offers a summary of findings.

\section{DATA AND ANALYTICAL MODELS}

\subsection{Data collection}

A sample of 411 borrowing and non-borrowing households was interviewed in 2008 in the peri-urban District 9, Ho Chi Minh City (HCMC), Vietnam. Since our focus is poor households in the credit market, the sample was selected from a list of poor households whose initial income per capita was below the HCMC general poverty line of VND 6 million (approximately US $\$ 1$ per day). ${ }^{2} 411$ households were successfully interviewed, accounting for $26 \%$ of the total number of poor households in each of the selected wards in the district. The interviewed sample provides 304 borrowing households and 107 non-borrowing households, with 2,062 members, 955 (46.3\%) males and 1,102 (53.7\%) females. The sample is likely to be representative for the poor group whose initial income per capita is below the poverty line at the survey time in the district, but will not be representative for Ho Chi Minh City nor for Vietnam.

The survey was designed to collect data on household and individual demographic-economic variables, commune characteristics, household durable and fixed assets, child schooling and education expenditure, healthcare, food, non-food, housing expenditure, and borrowing activities. We also utilized GPS receivers to collect data on the location of households and facilities in order to measure distances from each household to the facilities. The surveyed areas are located in the most socio-economically dynamic region, HCMC in Vietnam. The city is the largest economicfinancial centre in the country. It accounts for only $6.6 \%$ of the country's population but one third of Vietnam's Gross Domestic Product (GDP). The city's economy has recently been growing at above $10 \%$ per annum.

The surveyed district is the $5^{\text {th }}$ lowest population density district, and one of the peri-urban districts of HCMC. When it was first established in 1997, the district relied heavily on agricultural production, but its economic

\footnotetext{
${ }^{2}$ The list was provided by the District Department of Labour, Invalids and Social Affairs.
} 
structure has changed drastically due to current fast industrialization and urbanization. Average growth rates of industrial production and services have been very high for the period $1997-2008$, namely $24.7 \%$ and $28.1 \%$ per annum respectively. The district population growth rate is very high, 59\% over the period 1997-2008. Population density within the surveyed district in 2008 is highly dispersed. Some wards are very highly populated (more urban wards) e.g. Phuoc Binh (PB) (18,981 people $\left./ \mathrm{km}^{2}\right)$, Tang Nhon Phu A (TNPA) $\left(6,546\right.$ people $\left./ \mathrm{km}^{2}\right)$, while others are relatively low (more rural wards), e.g. Long Phuoc (LP) (300 people $\left./ \mathrm{km}^{2}\right)$, Long Truong (577 people $/ \mathrm{km}^{2}$ ). The main economic activities of the district are non-farm economic activities such as industrial production, construction and services, accounting for more than $90 \%$. For our sample, $72 \%$ of household heads are small self-employed, shopkeepers, housewives, casual workers, factory workers and the unemployed.

\subsection{Analytical models}

\subsubsection{Econometric models for the probability of credit participation and credit constraints}

Credit participation means a household has chosen to borrow and has already borrowed, even the borrowed amounts may be at the market clearance point (or optimal point) or any points below the market clearance point if without interest subsidies. A household that has participated in borrowing activities has, of course, access to particular credit resources, whereas a household having access to credit may choose whether or not to participate in borrowing activities.

The aim of this study is to determine the factors affecting credit participation and credit constraints. Credit participation and credit constraints are binary variables where participating in credit (or being creditconstrained) takes a value of one, and zero if a household did not borrow (or not credit-constrained). Thus, to estimate the probability of credit participation and credit constraints when dependant variable $Y$ equals one given a set of explanatory variables $X_{\mathrm{i}}$, the probit model is employed. The probit model is written as follows.

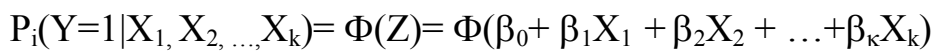

Where $P_{i}$ is the conditional probability of being a borrower (or creditconstrained) for the observation $i$, $\Phi$ is the standard cumulative normal, $X_{k}$ is 
the vector of explanatory variables and $\beta_{k}$ is the vector of coefficients to be estimated.

The existing literature suggests using physical and human capital endowments as explanatory variables to predict the probability of credit participation and credit constraints. The probit models include the household head's gender, age, education, marital status, household size, ${ }^{3}$ pre-survey income per capita, ${ }^{4}$ pre-survey assets (land/house/durable assets), ${ }^{5}$ a dummy variable for phone ownership, ${ }^{6}$ location dummies, and distance to the nearest bank. $^{7}$ The effects of other borrowing neighbours may affect the probability of credit participation and constraints because neighbouring households are likely to share information and borrowing experiences. So the proportion of borrowing neighbours within a radius of one kilometre of each respondent is used as a proxy for information flows. ${ }^{8}$ Accordingly, the probit model for credit participation is as follows:

$$
\text { BORROWER }_{\mathrm{ij}}=\beta_{0}+\beta_{1} \mathrm{X}_{1 \mathrm{ij}}+\beta_{2} \mathrm{X}_{2 \mathrm{ij}}+\beta_{3} \mathrm{X}_{3 \mathrm{j}}+\varepsilon_{\mathrm{ij}}
$$

where $B O R R O W E R_{i j}$ is a binary variable representing whether household $i$ in ward $j$ borrowed (1) or not (0), $X_{l i j}$ is a vector of household characteristics and $X_{2 i j}$ is the physical endowment of household $i$ in ward $j$, while $X_{3 j}$ is a vector of ward-level characteristics. These include the proportion of borrowing households within a radius of one kilometre and the distance to the nearest bank within a ward.

\footnotetext{
3 The number of under-18-year old children and the number of older-than-60-year old members are collinear with household size. However, the ratios of various age groups to total household size may not be collinear with household size, thus we ran a regression with the ratio of children to household size and the ratio of the older-than-60 years old members to household size, but the estimates are statistically insignificant. As a result, we dropped the variables.

${ }^{4}$ The income was collected by the District 9 Department of Labour, Invalids and Social Affairs in collaboration with the Hunger Elimination and Poverty Reduction Unit of each ward in the district from December 2005 to January 2006 in order to classify poor households who are eligible for receiving assistance including preferred loans from the HEPRF.

${ }^{5}$ We use only assets acquired over 24 months prior to our survey (rather than all assets) and pre-survey income (rather than current expenditure) to avoid possible endogeneity and reverse causality.

${ }^{6}$ We use the dummy as a proxy for information access; we do not classify phones as durable assets because recently phones, especially landline phones, are given free by the service suppliers. Subscribers have to pay connection fees, monthly fixed charges and actual call charges.

${ }^{7}$ To avoid the collinearity between ward dummy and the distance, the interactions between the distance and ward dummy are used instead of the distance itself.

${ }^{8}$ Alternatively, borrowing neighbours may create a crowding-out effect because they could be potential competitors when credit resources are limited.
} 
In equation (2), all borrowers are treated the same in the sense that there is no difference between those who borrowed from formal credit sources and those who borrowed from informal credit suppliers. However, it is possible that segmented markets may exist causing the determinants of who can borrow from formal credit to be distinct from the determinants of who can only borrow from informal credit. As a result, the multinomial (logit) model may help to uncover the roles of each factor in segmented credit markets. Accordingly, the model can be as follows:

$$
\text { SPECIFIED_BORROWER } \mathrm{ij}_{\mathrm{ij}}=\beta_{0}+\beta_{1} \mathrm{X}_{\mathrm{ij}}+\beta_{2} \mathrm{X}_{2 \mathrm{ij}}+\beta_{3} \mathrm{X}_{3 \mathrm{j}}+\varepsilon_{\mathrm{ij}}
$$

where SPECIFIED_BORROWER $\mathrm{i}_{\mathrm{ij}}$ is a multinomial variable representing whether a household $i$ in ward $j$ did not borrow $(\mathrm{N})$, or borrowed from the informal credit only (I), or from both the informal and formal credit (B), or from the formal credit only $(\mathrm{F}) ; \mathrm{X}_{\mathrm{s}}$ are as previously defined.

To examine the determinants of credit constraints, the following probit model is used:

$$
\text { CONSTRAINT }_{\mathrm{ij}}=\alpha_{0}+\alpha_{1} \mathrm{X}_{1 \mathrm{ij}}+\alpha_{2} \mathrm{X}_{2 \mathrm{ij}}+\alpha_{3} \mathrm{X}_{3 \mathrm{j}}+\mathrm{v}_{\mathrm{ij}}
$$

where CONSTRAINT $\mathrm{ij}_{\mathrm{ij}}$ is a binary variable representing whether household $i$ in ward $j$ is credit-constrained (1) or not (0). Credit-constrained households include rejected households, discouraged households, and partial borrowers; credit-unconstrained households consist of full borrowers and other households who do not want to borrow because they have sufficient resources to meet their demand for credit. $X_{s}$ were previously defined in the credit participation model.

\subsubsection{Tobit Type 2 model for credit amount received}

Regarding credit amounts received, the dependent variable is continuous and can vary between zero (for non-borrowers) and a certain positive value. Therefore in this case the Tobit model provides an appropriate estimator (Verbeek, 2004). The estimation equation is postulated as follows:

$$
\mathrm{Y}_{\mathrm{i}}^{*}=\beta \mathrm{Z}_{\mathrm{i}}+\mathrm{u}_{\mathrm{i}} \quad \mathrm{u}_{\mathrm{i}} \sim \mathrm{NID}\left(0, \sigma^{2}\right)
$$

$Y_{i}=\left\{\begin{array}{rll}\beta \mathrm{Z}_{\mathrm{i}}+\mathrm{u}_{\mathrm{i}} & \text { if } \mathrm{Y}_{\mathrm{i}}^{*}>0 & \text { for households when the borrowed amount } i \text { is positive } \\ 0 & \text { if } \mathrm{Y}_{\mathrm{i}}^{*} \leq 0 & \text { for households when the borrowed amount } i \text { is zero }\end{array}\right.$

where $\mathrm{Y}_{\mathrm{i}}{ }^{*}$ is the borrowed amount of household $i$, and $\mathrm{Z}_{\mathrm{i}}$ is a vector of explanatory variables. A shortcoming of the standard Tobit model is that the 
model may produce biased and inconsistent estimates if heteroscedasticity exists (Johnston, Dinardo, 1997). To overcome the problem, we use a Tobit Type 2 model to account for heteroscedasticity. The model is implemented by using the interval regression estimator, a generalisation of the Tobit model, where responses can be point data, interval data, left-censored or right-censored.

\section{RESULTS}

\subsection{Main features of poor households' credit}

Before discussing the econometric results, a general overview of poor households' credit in the peri-urban study areas of HCMC is provided. Formal credit provides $55 \%$ of credits, which is mainly from government subsidised sources such as the Vietnam Bank for Social Policy (VBSP), social political organisations, the Job Creation Support Fund (JCSF) and the Hunger Elimination and Poverty Reduction Fund (HEPRF). These lenders provide subsidised loans and are the main sources of credit, accounting for $51 \%$ of the total loans to the poor in the peri-urban areas (Table 1).

Table 1

Sources, sizes and interest rates of loans

\begin{tabular}{l|r|r|r|r|r}
\hline \multicolumn{1}{c|}{ Credit sector } & $\begin{array}{c}\text { Percent } \\
\text { In total }\end{array}$ & \multicolumn{2}{c|}{$\begin{array}{c}\text { Loan sizes } \\
\text { (VND 1,000) }\end{array}$} & \multicolumn{2}{c}{$\begin{array}{c}\text { Monthly interest } \\
\text { rates (\%) }\end{array}$} \\
\hline & \multicolumn{1}{c|}{$(\%)$} & \multicolumn{1}{c}{ Mean } & \multicolumn{1}{c}{ Std. Dev } & \multicolumn{1}{c}{ Mean } & Std. Dev \\
\hline \multicolumn{7}{c}{ By formal/informal sector } \\
\hline Formal & 55.26 & 9,327 & 33,421 & 0.78 & 0.70 \\
\hline Informal & 44.74 & 5,229 & 12,760 & 2.14 & 5.93 \\
\hline Friends, relatives \& neighbours & 36.35 & 4,308 & 11,780 & 0.033 & 0.27 \\
\hline Other informal sources & 8.39 & 9,218 & 15,870 & 11.29 & 9.22 \\
\hline \multicolumn{7}{|c|}{ By preferred sources } \\
\hline Subsidized loans & 51.00 & 5,503 & 6,725 & 0.76 & 0.72 \\
\hline Non-subsidized loans & 49.00 & 9,564 & 36,897 & 2.05 & 5.67 \\
\hline Overall & 100 & 7,494 & 26,330 & 1.40 & 4.05 \\
\hline
\end{tabular}

Source: own calculation from authors' survey

However, the informal credit sector still plays a substantial role in providing credit to the poor; approximately $45 \%$ of loans, albeit of a smaller average value than formal loans. Amongst informal credit providers, mutual assistance amongst relatives, friends and neighbours provide more than one 
third of all loans. The Rotating Saving and Credit Associations (ROSCAs), private moneylenders and pawnbrokers only provide $8.4 \%$ of total loans to the poor (Table 2). This small share may be because interpersonal trust and social ties are weak in peri-urban and urban areas (Allcott et al, 2007; Debertin; Hofferth, Iceland, 1998).

Interest rates for the poor's loans vary widely, from $0.78 \%$ per month on average for the formal credit to $2.14 \%$ (about $26 \%$ per year) for the informal sector with a large standard deviation of $5.9 \%$ (Table 2). The interest rate for informal credit is high compared to formal credit, but still lower than in many other developing countries. For example, a survey of 13 developing countries by Banerjee and Duflo (2010) shows that informal credit lenders charge annual rates of $40 \%$ to $80 \%$ per annum. However, when loans from friends, relatives and neighbours that are almost interest-free are excluded, the informal lenders charge very high interest rates at about $130 \%$ per year, as observed in many developing countries by Conning and Udry (2005). Informal credit lenders charge interest at $40 \%$ to $120 \%$ annually in Pakistan, $20 \%$ to $120 \%$ in India, $24 \%$ to $84 \%$ in rural Thailand, and over $90 \%$ in Nigeria.

Table 2

Demand for credit, credit participation and credit constraints

\begin{tabular}{l|r|r}
\hline \multicolumn{1}{c|}{ Specified categories } & \multicolumn{1}{c}{$\begin{array}{c}\text { Number } \\
\text { of households }\end{array}$} & $\begin{array}{c}\text { Percent } \\
\text { in total (\%) }\end{array}$ \\
\hline $\begin{array}{l}\text { Household has had a demand for credit in the past } \\
\text { 24 months prior to the survey? }\end{array}$ & 411 & 100 \\
\hline No, do not want to borrow & 76 & 18.49 \\
\hline Sufficient capital, do not need credit (a) & 35 & 8.52 \\
\hline Discouraged households (b) & 335 & 9.97 \\
\hline Yes, households need capital & 31 & 81.51 \\
\hline Was not lent any money (denied) (c) & 124 & 7.54 \\
\hline Was lent amounts lower than what households & 180 & 30.17 \\
wanted (d) & 411 & 43.80 \\
\hline Was lent fully (e) & 304 & 100 \\
\hline Credit participation in the past 24 months & 107 & 73.97 \\
\hline Borrowers (d \& e) & 411 & 26.03 \\
\hline Non-borrowers (a, b \& c) & 196 & 100 \\
\hline Credit constraints & 215 & 47.69 \\
\hline Credit-constrained (b, c \& d) & & 52.31 \\
\hline Credit-unconstrained (a \& e) & & \\
\hline
\end{tabular}

Source: own calculation from author's survey 
Our data shows that the main purpose of the loans taken by the poor in the peri-urban areas is for non-production (73.4\%). Consumption expenditure such as food, school fees and healthcare accounted for about $64 \%$ of total loans. On the other hand, only a quarter (in terms of both number of loans and loan value) is used for small production and businesses. This usage pattern is different from typical loan usage patterns in rural areas (Barslund, Tarp, 2007; Johnston, Morduch, 2007).

The data in Table 2 show the incidence of credit participation and credit constraints. Less than $10 \%$ of households had sufficient capital and did not want to borrow. Another 10\% were discouraged from seeking capital. Amongst those households seeking credit in the 24 months prior to our survey, $43.8 \%$ of all households had borrowed sufficiently, $30 \%$ borrowed amounts less than the value they demanded, and $7.5 \%$ were denied by credit providers. Overall, three quarters of the surveyed households borrowed in the 24 months prior to the survey (304 households). Almost all households had loans in both periods; 0-12 months and 12-24 months prior to the survey.

For credit participation, we simply treated households as borrowers if they had at least one loan during the 24 months prior to the survey, otherwise they were classified as non-borrowers. Meanwhile, potential borrowers are often excluded, discouraged, rejected, or rationed to smaller loans relative to what they might have optimally demanded; these potential borrowers are deemed credit-constrained. Accordingly, $48 \%$ of the surveyed households are credit-constrained. In addition, approximately $45 \%$ of the poor's loans were from the informal credit sector, and the poor might have been excluded from the formal credit, so we could regard them as the formal creditconstrained. If that was the case, the incidence of credit constraints would be higher than the current estimates suggest.

\subsection{Determinants of credit participation by the poor: An econometric analysis}

\subsubsection{The probit estimates}

The estimates from the probit models of the determinants of credit participation are presented in Table 3. Because of the highly heterogeneous population density across the wards and possible multicollinearity between the ward dummies and the distance to the nearest banks which varies mainly by ward), three separate model specifications are reported. 
Table 3

Marginal effects on the probability of credit participation (probit estimation)

\begin{tabular}{|c|c|c|c|}
\hline Explanatory variables & Model (1) & Model (2) & Model (3) \\
\hline Head's gender $($ male $=1)$ & $\begin{array}{r}-0.0285 \\
(0.55) \\
\end{array}$ & $\begin{array}{r}-0.0302 \\
(0.59) \\
\end{array}$ & $\begin{array}{r}-0.0211 \\
(0.41) \\
\end{array}$ \\
\hline Head's age (years) & $\begin{array}{r}-0.0073 \\
(4.29)^{* *} \\
\end{array}$ & $\begin{array}{r}-0.0072 \\
(4.28)^{* *}\end{array}$ & $\begin{array}{r}-0.0073 \\
(4.32) * * \\
\end{array}$ \\
\hline Head's education (years of schooling) & $\begin{array}{r}0.0017 \\
(0.22) \\
\end{array}$ & $\begin{array}{r}0.0019 \\
(0.27) \\
\end{array}$ & $\begin{array}{r}0.0027 \\
(0.37) \\
\end{array}$ \\
\hline Marital status (married=1) & $\begin{array}{l}-0.1033 \\
(1.86)+\end{array}$ & $\begin{array}{l}-0.0974 \\
(1.75)+\end{array}$ & $\begin{array}{l}-0.1094 \\
(1.95)+\end{array}$ \\
\hline Household size in $\log ^{(a)}$ & $\begin{array}{r}0.1932 \\
(3.56)^{* *} \\
\end{array}$ & $\begin{array}{r}0.1951 \\
(3.63)^{* *}\end{array}$ & $\begin{array}{r}0.1932 \\
(3.59)^{* *}\end{array}$ \\
\hline Pre-survey income per capita in log & $\begin{array}{l}0.1781 \\
(2.15)^{*}\end{array}$ & $\begin{array}{l}0.1730 \\
(2.13)^{*}\end{array}$ & $\begin{array}{l}0.1884 \\
(2.28)^{*}\end{array}$ \\
\hline $\begin{array}{l}\text { Pre-survey assets in log (assets acquired } \\
\text { over } 24 \text { months prior to survey) }\end{array}$ & $\begin{array}{r}-0.0010 \\
(0.06) \\
\end{array}$ & $\begin{array}{r}0.0018 \\
(0.11) \\
\end{array}$ & $\begin{array}{r}-0.0014 \\
(0.09) \\
\end{array}$ \\
\hline Phone ownership (yes=1) & $\begin{array}{l}0.1309 \\
(2.26)^{*}\end{array}$ & $\begin{array}{l}0.1232 \\
(2.14)^{*}\end{array}$ & $\begin{array}{r}0.1389 \\
(2.34)^{*}\end{array}$ \\
\hline Phuoc Binh - PB (urban) & $\begin{array}{r}0.0185 \\
(0.27) \\
\end{array}$ & & \\
\hline Long Truong - LT (rural) & $\begin{array}{r}0.1570 \\
(2.58)^{* *} \\
\end{array}$ & & \\
\hline Long Phuoc - LP (rural) & $\begin{array}{r}0.1146 \\
(1.95)+ \\
\end{array}$ & & \\
\hline \multicolumn{4}{|l|}{ Interaction terms } \\
\hline Borrowing neighbour proportion $\mathrm{x}$ TNPA & & $\begin{array}{r}-0.6642 \\
(1.95)+ \\
\end{array}$ & \\
\hline Borrowing neighbour proportion $\mathrm{x} P \mathrm{~B}$ & & $\begin{array}{l}-0.5928 \\
(1.81)+ \\
\end{array}$ & \\
\hline Borrowing neighbour proportion $\mathrm{x}$ LT & & $\begin{array}{r}-0.3297 \\
(1.14) \\
\end{array}$ & \\
\hline Borrowing neighbour proportion $\mathrm{x}$ LP & & $\begin{array}{r}-0.3921 \\
(1.35) \\
\end{array}$ & \\
\hline Distance to nearest bank $(\mathrm{km}) \times \mathrm{TNPA}$ & & & $\begin{array}{r}-0.0968 \\
(1.20) \\
\end{array}$ \\
\hline Distance to nearest bank $(\mathrm{km}) \times \mathrm{PB}$ & & & $\begin{array}{r}-0.1534 \\
(1.06) \\
\end{array}$ \\
\hline Distance to nearest bank $(\mathrm{km}) \times \mathrm{LT}$ & & & $\begin{array}{r}0.1277 \\
(2.09)^{*}\end{array}$ \\
\hline Distance to nearest bank $(\mathrm{km}) \times \mathrm{LP}$ & & & $\begin{array}{r}0.0113 \\
(0.70) \\
\end{array}$ \\
\hline Wald $\chi^{2}$ test & $44.56 * *$ & $46.80 * *$ & $53.35 * *$ \\
\hline $\operatorname{Prob}>\chi^{2}$ & 0.0000 & 0.0000 & 0.0000 \\
\hline Predicted probability at $\mathrm{x}$ bar & 0.760 & 0.761 & 0.763 \\
\hline Pseudo $\mathrm{R}^{2}$ & 0.12 & 0.12 & 0.13 \\
\hline Observations & 411 & 411 & 411 \\
\hline
\end{tabular}

Notes: Robust $\mathrm{z}$ statistics in parentheses; statistically significant at $10 \%(+)$, at $5 \%(*)$, and at $1 \%(* *)$. Tang Nhon PhuA (TNPA) ward is set as a base for ward dummies. ${ }^{(a)}$ The marginal effect of household size (hhsize) on the predicted probability is calculated as $\mathrm{dY} / \mathrm{d}(\mathrm{hhsize})=\beta .(1 / \mathrm{hhsize})$, ceteris paribus. 
The estimates reveal several determinants of credit participation by the poor in peri-urban areas (Table 3). Households with older household heads and those currently married have a lower probability of borrowing. The fact is that households with unmarried heads have a smaller household size and have to borrow to smooth consumption when they have adverse shocks because they are not able to increase labour income (Kochar, 1999). The estimates also show that larger households are more likely to borrow, perhaps they may have lower credit risks because of more relationships with community and more diversified sources of income (Schreiner and Nagarajan, 1998). It is also the case that richer households are more likely to be borrowers. The pre-survey income per capita, which is closely associated with labour income of the poor, has a significantly positive impact on credit participation. In contrast, the value of fixed assets such as house, land, and other durable asset acquired over the 24 months prior to the survey have no impacts on borrowing. The poor in peri-urban areas often lack or have incomplete legal documentation for the assets, e.g. land-use right certificates and house ownership certificates (Kim, 2004) because they do not have enough money to pay fees and/or do not know how and where to get the certificates done due to a too complicated procedure, hence their assets are not appropriate to be lodged as collateral for their desired loans.

There is no gender bias in microcredit participation in the peri-urban areas, in contrast to what is found by Barslund and Tarp (2007) and Nguyen (2007) in rural Vietnam. Our results also show that the education of household heads does not significantly influence credit participation. The poor's household heads in our survey have a low education, only 4.7 years of schooling compared to 8.8 and 10 years of schooling for non-wage and wage earners of the general population in Vietnam surveyed in 2008 (Doan, Gibson, 2012). Moreover, these poor household heads usually work in unskilled sectors, such as grocery shopkeepers, factory workers, housewives and casual workers, where education is not well rewarded. Our finding is contrary to other studies from rural areas in developing countries where education has an important role in credit participation (Swain, 2007; Zeller, 1994).

Households' dwelling location is an important determinant of credit market participation in the peri-urban areas. Almost all loans by the poor are small, collateral-free, and mainly based on social capital or interpersonal trust. Households in the more rural parts of the surveyed area have better social capital than more urban households, thus they have a higher likelihood of credit participation. This is shown by the significantly positive 
coefficients of two rural ward dummies, Long Truong (LT) and Long Phuoc (LP), in column 1 of Table $3 .{ }^{9}$ When exploring the role of distance within each ward, in the rural ward of Long Truong (LT), households that are located far from the nearest bank (also located far from the ward centre) are also found more likely to borrow (Figure 1). ${ }^{10}$ This re-confirms the role of social relationship and interpersonal trust in credit transactions in peri-urban areas.

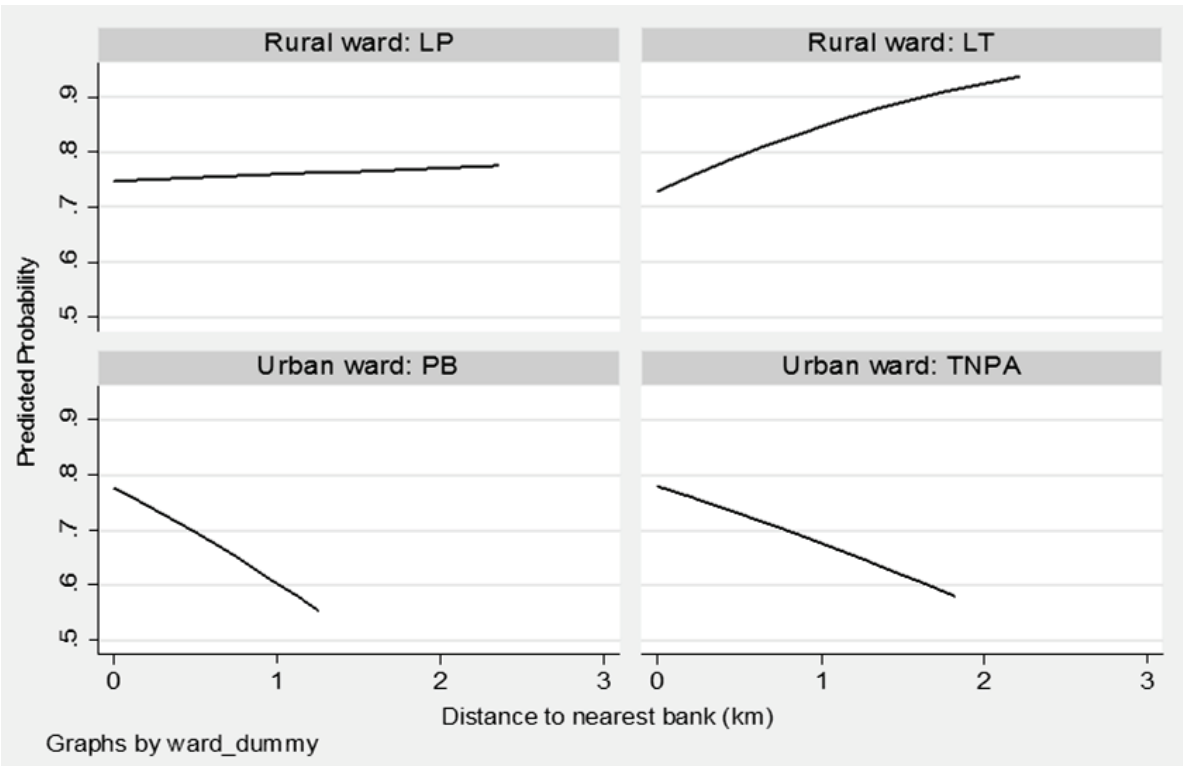

Figure 1. Predicted probabilities of credit participation by distance to the nearest bank

The data exploration shows that most borrowing households $(56 \%)$ in urban wards (TNPA and PB) borrowed from the formal (subsidized) credit channels, while most borrowing households in rural wards (LT and LP) borrowed from the informal credit sector. This means that the more rural poor households rely more on informal credit, whereas their more urban counterparts rely on government subsidized funds.

\footnotetext{
${ }^{9}$ The inclusion of distance to nearest market (interacted with ward dummies) in the models gives similar result as the distance to nearest bank, thus we do not report the results of the regression with the distance to nearest market.

${ }^{10}$ In the LT ward, households located far from the centre are rural household farmers or casual workers, while households located near the ward centre are small traders, grocery shop keepers. In the LP ward, all the households are involved in rural economic activities.
} 
The impact of distance to the nearest banks and the main sources of the poor's credit in rural and urban areas could imply that households located far from ward centres (dwelling in rural countryside) could have better community relationships and interpersonal trust; better social capital help ease access to informal credit sources, such as relatives, neighbours, friends, and other credit providers who mainly lend money on the basis of interpersonal trust rather than collateral.

The proportion of borrowing neighbours influences negatively and significantly the likelihood of borrowing in urban wards (TNPA and PB), but not in rural wards (LT and LP, Table 3, column 2). This implies that households in urban areas compete against their neighbours in accessing limited credit resources from subsidized funds, but this is not the case in the rural wards because the poor there rely more on informal credit.

In summary, household size, younger households, initial income, phone ownership, and living in more rural countryside areas are important determinants of credit participation by the peri-urban poor. On the other hand, gender, education and assets do not matter in the credit participation of poor households. Furthermore, households in rural wards with presumably better relationships and interpersonal trust have advantages in accessing credit, especially informal credit. Competition by other borrowing neighbours in accessing credit resources, especially subsidized funds, is also an influential factor for credit participation by the poor in urban areas.

\subsubsection{Tobit Type 2 for loan amounts received by the poor}

The Tobit model estimates in Table 4 reveal some key findings: First, gender does not really matter in credit participation as found and discussed in the preceding section, but it plays a role in explaining loan size. Maleheaded households received lower amounts of loans than female-headed households. The finding is contrary to the common trend in developing countries because females are often involved in small businesses which need smaller loans (Armendariz, Morduch, 2010), while in peri-urban areas, loans are mainly used for non-production. Second, the age of household heads has a slightly positive effect on loan size. The older households tend to borrow larger loans, with a loan maximum at about 46 years of age. Very young or very old headed-households have a smaller labour force, and hence have a lower ability to repay. They therefore may be lent smaller amounts, or they themselves favour smaller loans to fit with their demand and ability to repay. Third, the initial income per capita and household sizes are important 
Table 4

Interval regression (Tobit Type 2) for loan amounts received

\begin{tabular}{|c|c|c|c|}
\hline Explanatory Variable & Model (1) & Model (2) & Model (3) \\
\hline Head's gender $($ male $=1)$ & $\begin{array}{r}-3,962.37 \\
(2.01)^{*} \\
\end{array}$ & $\begin{array}{r}-3,977.1 \\
(2.02)^{*} \\
\end{array}$ & $\begin{array}{r}-3,762.87 \\
(1.92)+ \\
\end{array}$ \\
\hline Head's age (years) & $\begin{array}{r}528.75 \\
(1.45) \\
\end{array}$ & $\begin{array}{r}525.4 \\
(1.43) \\
\end{array}$ & $\begin{array}{r}500.85 \\
(1.37) \\
\end{array}$ \\
\hline Head's age squared & $\begin{array}{r}-5.57 \\
(1.78)+ \\
\end{array}$ & $\begin{array}{r}-5.50 \\
(1.75)+ \\
\end{array}$ & $\begin{array}{r}-5.38 \\
(1.72)^{+}\end{array}$ \\
\hline Head's education (years) & $\begin{array}{r}147.38 \\
(0.51) \\
\end{array}$ & $\begin{array}{r}153.9 \\
(0.53) \\
\end{array}$ & $\begin{array}{r}142.50 \\
(0.47) \\
\end{array}$ \\
\hline Marital status (married $=1$ ) & $\begin{array}{r}1,972.25 \\
(0.90) \\
\end{array}$ & $\begin{array}{r}2,041.4 \\
(0.94) \\
\end{array}$ & $\begin{array}{r}1,762.18 \\
(0.81) \\
\end{array}$ \\
\hline Household size in log & $\begin{array}{r}4,621.38 \\
(2.48)^{*}\end{array}$ & $\begin{array}{l}4,631.5 \\
(2.48)^{*}\end{array}$ & $\begin{array}{r}4,636.29 \\
(2.43)^{*}\end{array}$ \\
\hline Pre-survey income per capita in log & $\begin{array}{r}7,322.34 \\
(2.01)^{*}\end{array}$ & $\begin{array}{l}7,252.5 \\
(2.02)^{*}\end{array}$ & $\begin{array}{r}7,272.70 \\
(1.98)^{*}\end{array}$ \\
\hline $\begin{array}{l}\text { Pre-survey assets in log (assets acquired } \\
\text { over } 24 \text { months prior to survey) }\end{array}$ & $\begin{array}{r}624.64 \\
(1.14) \\
\end{array}$ & $\begin{array}{r}653.2 \\
(1.19) \\
\end{array}$ & $\begin{array}{r}572.99 \\
(1.04) \\
\end{array}$ \\
\hline Phone ownership (yes $=1)$ & $\begin{array}{l}5,024.36 \\
(2.89)^{* *}\end{array}$ & $\begin{array}{r}4,963.4 \\
(2.85)^{* *}\end{array}$ & $\begin{array}{l}4,965.04 \\
(2.81)^{* *}\end{array}$ \\
\hline Phuoc Binh - PB (urban) & $\begin{array}{r}-1,606.15 \\
(0.61) \\
\end{array}$ & & \\
\hline Long Truong - LT (rural) & $\begin{array}{r}2,389.45 \\
(1.09) \\
\end{array}$ & & \\
\hline Long Phuoc - LP (rural) & $\begin{array}{r}874.92 \\
(0.41) \\
\end{array}$ & & \\
\hline \multicolumn{4}{|l|}{ Interaction terms } \\
\hline Borrowing neighbour proportion $\mathrm{x}$ TNPA & & $\begin{array}{r}-6,635.6 \\
(0.82) \\
\end{array}$ & \\
\hline Borrowing neighbour proportion $\mathrm{x}$ PB & & $\begin{array}{r}-8,489.4 \\
(1.15) \\
\end{array}$ & \\
\hline Borrowing neighbour proportion $\mathrm{x}$ LT & & $\begin{array}{r}-2,397.1 \\
(0.38) \\
\end{array}$ & \\
\hline Borrowing neighbour proportion $\mathrm{x}$ LP & & $\begin{array}{r}-4,124.7 \\
(0.60) \\
\end{array}$ & \\
\hline Distance to nearest bank $(\mathrm{km}) \times \mathrm{TNPA}$ & & & $\begin{array}{r}-2,526.62 \\
(0.87) \\
\end{array}$ \\
\hline Distance to nearest bank $(\mathrm{km}) \times \mathrm{PB}$ & & & $\begin{array}{r}-7,899.71 \\
(1.53) \\
\end{array}$ \\
\hline Distance to nearest bank $(\mathrm{km}) \times \mathrm{LT}$ & & & $\begin{array}{r}304.95 \\
(0.18) \\
\end{array}$ \\
\hline Distance to nearest bank $(\mathrm{km}) \mathrm{x} \mathrm{LP}$ & & & $\begin{array}{r}-280.37 \\
(0.54) \\
\end{array}$ \\
\hline Constant & $\begin{array}{l}-85,633 \\
(2.40)^{*}\end{array}$ & $\begin{array}{l}-81,289 \\
(2.25)^{*}\end{array}$ & $\begin{array}{l}-81,505 \\
(2.28)^{*}\end{array}$ \\
\hline Wald $\chi^{2}$ test & $28.32 * *$ & $29.42 * *$ & $27.22 *$ \\
\hline Prob $>\chi^{2}$ & 0.0050 & 0.0057 & 0.0116 \\
\hline Sigma (test for Tobit model) & $\begin{array}{r}13720.32 \\
(8.90)^{* *} \\
\end{array}$ & $\begin{array}{r}13722.66 \\
(8.89)^{* *} \\
\end{array}$ & $\begin{array}{r}13715.53 \\
(8.94)^{* *} \\
\end{array}$ \\
\hline Observations & 405 & 405 & 405 \\
\hline
\end{tabular}

Notes: Robust $\mathrm{z}$ statistics in parentheses; statistically significant at $10 \%(+)$, at $5 \%(*)$, and at $1 \%(* *)$. Five extreme outliers of loan amount are dropped. 
determinants of loan size, an increase in household size would help increase labour income and diversify income sources (Schreiner, Nagarajan, 1998), and also increase demand for consumption. Finally, the education level of the household heads, the head's marital status, the assets acquired prior to borrowing, location dummies, the distance to the nearest banks and the proportion of borrowing neighbours make no significant difference to loan sizes.

\subsubsection{The Multinomial logit estimates for credit participation}

The binary probit models help examine the roles of household characteristics and endowments in credit participation, regardless of credit sources and of the possibly different roles of each factor in specified credit market segments. Pooling credit market segments would conceal the roles of each factor. Therefore, to provide more nuanced insights, the surveyed households are classified into four groups: non-borrowing, borrowing from informal credit, borrowing from formal credit, and borrowing from both informal and formal credit. The multinomial logit model (MNL) is then employed to examine the factors influencing the probability of specified credit participation.

Amongst the 411 households, $26.0 \%$ of the surveyed households did not borrow, $23.6 \%$ borrowed from only informal sources, $25.3 \%$ borrowed from only formal sources, and $26.0 \%$ borrowed from both formal and informal credit. The purpose of the MNL model is to compare each outcome probability with the base outcome of the non-borrowing group. The estimates are presented in Table 5 in the form of the relative risk ratios (RRR) outcome of MNL models.

\section{Household heads' gender and age}

To interpret the estimated coefficients, we provide two illustrations: a dummy (e.g. gender) and a continuous variable coefficient $\beta$ (e.g. age). The head's gender coefficient $e^{\beta 1}=1.3865$ (Table 5, Model 1, column 1) means that the probability of borrowing from informal credit by males is $38.65 \%$ higher than for females. Similarly, $\mathrm{e}^{\beta 3}=0.8756$ means that the probability of borrowing from formal credit by males is $12.44 \%$ lower than for females. For a continuous variable of head's age, the RRR is about 0.96 across models and sources of credit, smaller than one, meaning that when a household head becomes an additional year older, the ratio of credit participation probability will decline by about $4 \%$, ceteris paribus. 


\section{Household size, phone ownership, and pre-survey income}

The estimates show that the ratios of borrowing probability increase with household size in all credit market segments. Similarly, having a phone has a positive influence on the likelihood of participation in all credit markets, but the effect is highly significant only for the formal credit. Similarly, the presurvey income per capita positively affects credit participation in all credit market segments (Table 5 and Figure 2).

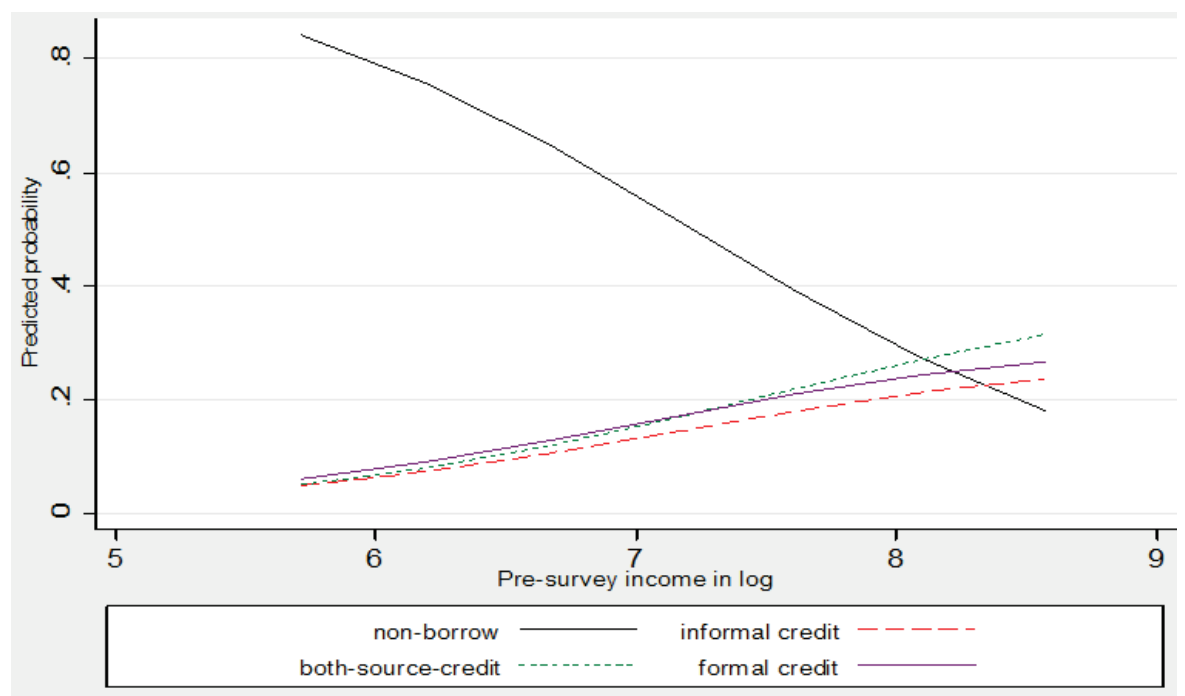

Note: A downward slope of the line shows the declining probability of being nonborrowers as the income increases

Figure 2: Predicted probabilities of participation in specified credit sources by annually pre-survey income (in logarithm)

\section{Marital status of household heads}

As expected, households with a single head such as the divorced, separated, widowed and unmarried tend to borrow more from informal credit than the married-head households. These single-head households have less ability to smooth consumption by themselves if they face adverse shocks, especially demographic shocks, because they do not have enough working members to increase income by increasing labour working hours. Therefore they are forced to borrow, especially from informal credit as discussed in Kochar (1995). 


\section{Proportion of borrowing neighbours: Competition or crowding-out effects}

The estimates of the interactions between the proportion of borrowing neighbours and ward dummies reveals that there is a crowding-out effect from the neighbours in accessing only formal subsidised credit in all the wards. For example, the RRR is 0.0159 (Table 5, Model 2, column 3), meaning that when the rate of borrowing neighbours in the LP ward increases by 10 percentage points, the ratio of formal credit participation probability will decline by about $9.8 \%$, ceteris paribus.

\section{Household dwelling locations and distance to the nearest banks}

In addition, loans to the poor are small, collateral-free, and based mainly on social capital or interpersonal trust. As discussed earlier, households in the rural wards have more advantages compared to urban households when accessing informal and both-credit sources, hence the RRR ratio of credit participation probability in informal and both-credit-sources by households in rural wards (LT and LP) is higher (Table 5, Model 1). The distance and locations which proxy for the degree of rurality and closer community relationships help households get informal credit.

In contrast, greater distance and living in rural areas may increase the physical barriers to getting formal credit. However, household dwelling locations and distance to the nearest bank do not affect the ratios of probability of formal credit participation. In other words, formal credit is evenly distributed across the wards (Table 5 , Model 1, column 3 ) and within each ward (Table 5, Model 3, column 3). When considering distance to the nearest banks within each ward, the distance does not significantly affect the ratio of probability of informal credit participation in the urban wards, but it positively affects the ratio of probability of informal credit participation in rural wards. In other words, the ratios of probability of informal credit participation increase significantly with distance to the nearest banks only in rural wards (Figure 1).In short, households in rural wards have a greater propensity to borrow from informal credit compared to urban households; and within a rural ward, households located far from ward centres rely more on informal credit because of better social relationship.

\section{Other insignificant factors}

Controlling for other variables, education and the initial assets play no significant role in credit participation even in the formal credit sector. However, as previously discussed, most formal credit to poor households in 
the study areas are from the government subsidized funds such as the HEPRF, VBSP, and other supporting funds, but very few of the loans are from commercial banks. Consequently, the key lenders require neither collateral nor specific education when making lending decisions.

Table 5

Estimates of multinomial logit model with relative risk ratios (RRR) for credit participation in specified credit sources

\begin{tabular}{|c|c|c|c|c|c|c|c|c|c|}
\hline \multirow{4}{*}{$\begin{array}{c}\text { Explanatory } \\
\text { Variables }\end{array}$} & \multicolumn{3}{|c|}{ Model 1} & \multicolumn{3}{|c|}{ Model 2} & \multicolumn{3}{|c|}{ Model 3} \\
\hline & \multicolumn{3}{|c|}{$\mathbf{R R R}^{(\mathbf{b})}$ Outcome for } & \multicolumn{3}{|c|}{ RRR Outcome for } & \multicolumn{3}{|c|}{ RRR Outcome for } \\
\hline & $\begin{array}{c}\text { Informal } \\
\text { Credit }\end{array}$ & $\begin{array}{l}\text { Both- } \\
\text { source } \\
\text { Credit } \\
\end{array}$ & $\begin{array}{c}\text { Formal } \\
\text { Credit }\end{array}$ & $\begin{array}{c}\text { Informal } \\
\text { Credit }\end{array}$ & $\begin{array}{c}\text { Both- } \\
\text { source } \\
\text { Credit } \\
\end{array}$ & $\begin{array}{c}\text { Formal } \\
\text { Credit }\end{array}$ & $\begin{array}{c}\text { Informal } \\
\text { Credit }\end{array}$ & $\begin{array}{l}\text { Both- } \\
\text { source } \\
\text { Credit } \\
\end{array}$ & $\begin{array}{r}\text { Formal } \\
\text { Credit }\end{array}$ \\
\hline & $22.63 \%$ & $26.03 \%$ & $25.30 \%$ & $22.63 \%$ & $26.03 \%$ & $25.30 \%$ & $22.63 \%$ & $26.03 \%$ & $25.30 \%$ \\
\hline $\begin{array}{l}\text { Head's gender } \\
(\text { male }=1)\end{array}$ & $\begin{array}{r}1.3865 \\
(0.87) \\
\end{array}$ & $\begin{array}{r}0.5995 \\
(1.43) \\
\end{array}$ & $\begin{array}{c}0.8756 \\
(0.36) \\
\end{array}$ & $\begin{array}{r}1.3846 \\
(0.87) \\
\end{array}$ & $\begin{array}{r}0.6006 \\
(1.43) \\
\end{array}$ & $\begin{array}{r}0.8604 \\
(0.41) \\
\end{array}$ & $\begin{array}{r}1.6307 \\
(1.23) \\
\end{array}$ & $\begin{array}{r}0.6397 \\
(1.25) \\
\end{array}$ & $\begin{array}{r}0.8694 \\
(0.38) \\
\end{array}$ \\
\hline Head's age & $\begin{array}{r}0.9534 \\
(3.81)^{* *} \\
\end{array}$ & $\begin{array}{r}0.9628 \\
(3.38) * * \\
\end{array}$ & $\begin{array}{r}0.9641 \\
(3.07) * * \\
\end{array}$ & $\begin{array}{r}0.9539 \\
(3.79)^{* *} \\
\end{array}$ & $\begin{array}{r}0.9633 \\
(3.35)^{* *} \\
\end{array}$ & $\begin{array}{r}0.9644 \\
(3.03) * * \\
\end{array}$ & $\begin{array}{r}0.9524 \\
(3.79)^{* *} \\
\end{array}$ & $\begin{array}{r}0.9614 \\
(3.48)^{* *} \\
\end{array}$ & $\begin{array}{r}0.9645 \\
(3.05)^{* *} \\
\end{array}$ \\
\hline $\begin{array}{l}\text { Head's } \\
\text { education } \\
\text { (years) }\end{array}$ & $\begin{array}{r}0.9523 \\
(0.91)\end{array}$ & $\begin{array}{r}1.0346 \\
(0.67)\end{array}$ & $\begin{array}{r}1.0179 \\
(0.35)\end{array}$ & $\begin{array}{r}0.9555 \\
(0.85)\end{array}$ & $\begin{array}{r}1.0381 \\
(0.74)\end{array}$ & $\begin{array}{r}1.0165 \\
(0.32)\end{array}$ & $\begin{array}{r}0.9598 \\
(0.76)\end{array}$ & $\begin{array}{r}1.0311 \\
(0.60) \\
\end{array}$ & $\begin{array}{r}1.0264 \\
(0.52)\end{array}$ \\
\hline $\begin{array}{l}\text { Marital status } \\
(\text { married=1) }\end{array}$ & $\begin{array}{l}0.3492 \\
(2.55)^{*} \\
\end{array}$ & $\begin{array}{r}0.7396 \\
(0.76) \\
\end{array}$ & $\begin{array}{r}0.6627 \\
(1.01) \\
\end{array}$ & $\begin{array}{l}0.3616 \\
(2.47)^{*} \\
\end{array}$ & $\begin{array}{r}0.7390 \\
(0.77) \\
\end{array}$ & $\begin{array}{r}0.7269 \\
(0.79) \\
\end{array}$ & $\begin{array}{r}0.3084 \\
(2.66)^{* *} \\
\end{array}$ & $\begin{array}{r}0.6911 \\
(0.92) \\
\end{array}$ & $\begin{array}{r}0.6253 \\
(1.14) \\
\end{array}$ \\
\hline $\begin{array}{l}\text { Household size } \\
\text { in logarithm }\end{array}$ & $\begin{array}{l}2.2269 \\
(2.17)^{*} \\
\end{array}$ & $\begin{array}{r}3.2430 \\
(3.15)^{* *} \\
\end{array}$ & $\begin{array}{r}.3899 \\
(3.23) * * \\
\end{array}$ & $\begin{array}{l}2.2499 \\
(2.20)^{*} \\
\end{array}$ & $\begin{array}{r}3.2414 \\
(3.12)^{* *} \\
\end{array}$ & \begin{tabular}{|r|}
3.4761 \\
$(3.31) * *$ \\
\end{tabular} & $\begin{array}{r}2.0855 \\
(1.96)^{*} \\
\end{array}$ & $\begin{array}{r}3.5470 \\
(3.37)^{* *} \\
\end{array}$ & $\begin{array}{r}3.3700 \\
(3.22)^{* *} \\
\end{array}$ \\
\hline $\begin{array}{l}\text { Pre-survey } \\
\text { income } \\
\text { in logarithm }\end{array}$ & $\begin{array}{r}2.6851 \\
(1.66)^{+} \\
\end{array}$ & $\begin{array}{l}3.7543 \\
(2.11)^{*} \\
\end{array}$ & $\begin{array}{r}2.4145 \\
(1.70)^{+} \\
\end{array}$ & $\begin{array}{r}2.5350 \\
(1.58) \\
\end{array}$ & $\begin{array}{l}3.4970 \\
(2.01)^{*}\end{array}$ & $\begin{array}{r}2.3867 \\
(1.65)^{+} \\
\end{array}$ & $\begin{array}{c}2.9895 \\
(1.71)^{+} \\
\end{array}$ & $\begin{array}{l}3.2606 \\
(2.07)^{*} \\
\end{array}$ & $\begin{array}{r}2.8708 \\
(1.99)^{*} \\
\end{array}$ \\
\hline $\begin{array}{l}\text { Pre-survey } \\
\text { assets in } \\
\text { logarithm } \\
\end{array}$ & $\begin{array}{r}1.0871 \\
(0.69) \\
\end{array}$ & $\begin{array}{r}0.9553 \\
(0.38) \\
\end{array}$ & $\begin{array}{l}0.9591 \\
(0.35) \\
\end{array}$ & $\begin{array}{l}1.1010 \\
(0.80) \\
\end{array}$ & $\begin{array}{l}0.9578 \\
(0.36) \\
\end{array}$ & $\begin{array}{r}0.9756 \\
(0.21) \\
\end{array}$ & $\begin{array}{r}1.1197 \\
(0.91) \\
\end{array}$ & $\begin{array}{r}0.9367 \\
(0.54) \\
\end{array}$ & $\begin{array}{r}0.9351 \\
(0.57) \\
\end{array}$ \\
\hline $\begin{array}{l}\text { Phone } \\
\text { ownership } \\
(y e s=1)\end{array}$ & $\begin{array}{r}1.4456 \\
(1.00) \\
\end{array}$ & $\begin{array}{r}1.7160 \\
(1.45) \\
\end{array}$ & $\begin{array}{r}3.4660 \\
(2.98)^{* *}\end{array}$ & $\begin{array}{r}1.3881 \\
(0.89) \\
\end{array}$ & $\begin{array}{r}1.6439 \\
(1.35) \\
\end{array}$ & $\begin{array}{r}3.4750 \\
(2.95)^{* *} \\
\end{array}$ & $\begin{array}{r}1.5408 \\
(1.11) \\
\end{array}$ & $\begin{array}{r}1.7119 \\
(1.42) \\
\end{array}$ & $\begin{array}{r}3.4014 \\
(2.89)^{* *} \\
\end{array}$ \\
\hline $\begin{array}{l}\text { PB ward } \\
\text { (urban) }\end{array}$ & $\begin{array}{c}0.3026 \\
(1.83)+ \\
\end{array}$ & $\begin{array}{r}1.5091 \\
(0.80) \\
\end{array}$ & $\begin{array}{r}1.3147 \\
(0.63) \\
\end{array}$ & & & & & & \\
\hline LT ward (rural) & $\begin{array}{r}3.3774 \\
(2.68) * * \\
\end{array}$ & $\begin{array}{r}6.0195 \\
(3.78)^{* *}\end{array}$ & $\begin{array}{r}0.6904 \\
(0.76) \\
\end{array}$ & & & & & & \\
\hline LP ward (rural) & $\begin{array}{r}1.7661 \\
(1.31) \\
\end{array}$ & $\begin{array}{r}4.0763 \\
(3.15)^{* *}\end{array}$ & $\begin{array}{r}1.2173 \\
(0.46)\end{array}$ & & & & & & \\
\hline
\end{tabular}


(Continued next page)

Continued table 5

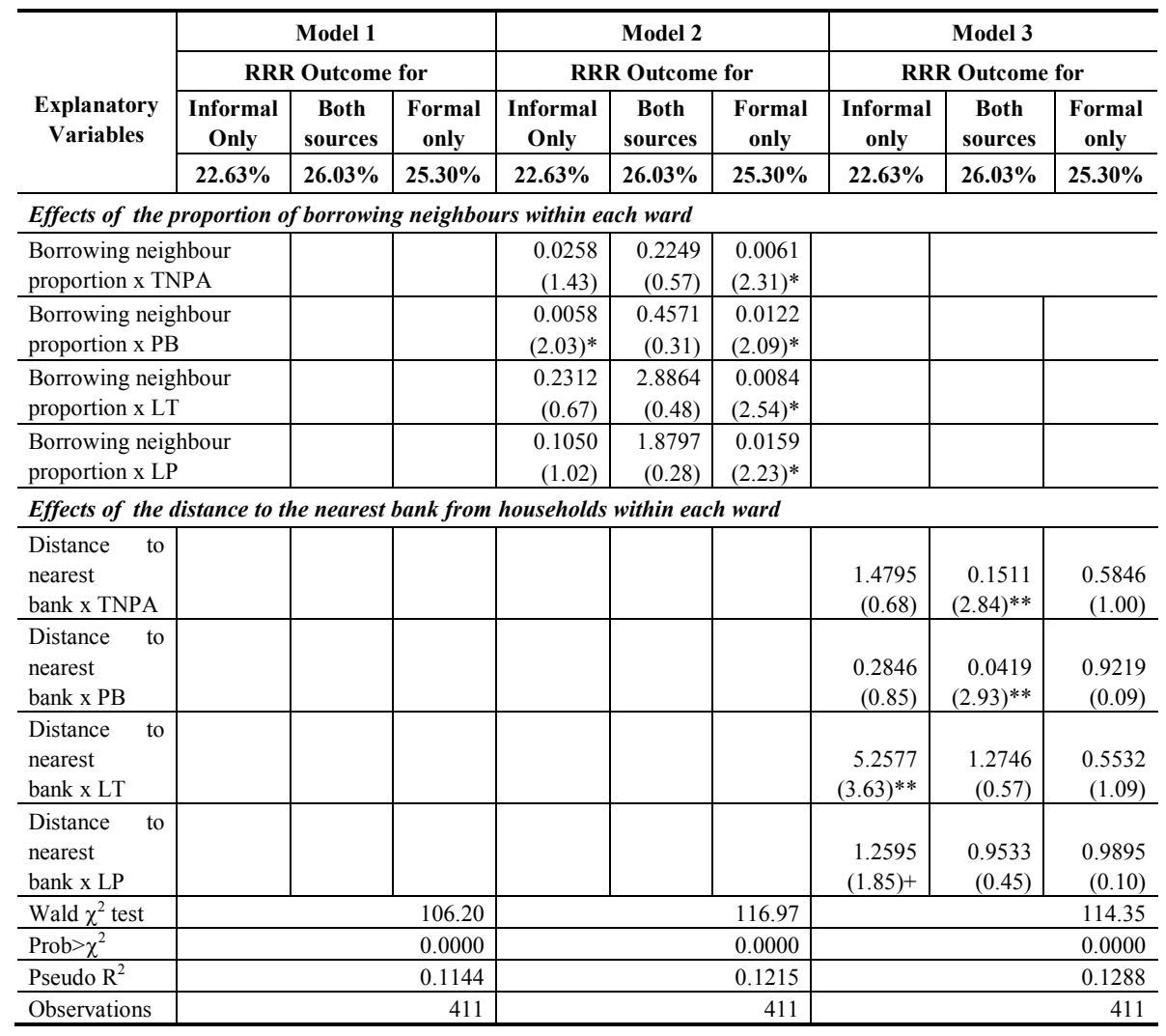

Notes: Robust z statistics in parentheses; statistically significant at $10 \%(+)$, at $5 \%(*)$, and at $1 \%(* *)$; the base outcome $(0)$ is non-borrowing households (non-borrowers which accounts for $26.03 \%$ observations). ${ }^{(b)}$ RRR coefficient is exponential coefficient $=e^{\beta}=\exp (\beta)$, e.g. $\exp (0.3268)=1.3865$ where $\beta=0.3268$ is the estimated outcome of the standard multinomial logit model.

In summary, age, household size, and pre-treatment income have important roles in all credit market segments. In contrast, gender, education, and pre-survey assets are found to have no role in credit participation in any specified credit market segments. The household's location, phone ownership, and marital status of household heads have different roles in different credit segments for the poor in the peri-urban areas. Finally, credit subsidies may result in an excess of credit demand and a crowding-out effect amongst the borrowers. 


\subsection{Determinants of credit constraints of poor households}

Though $74 \%$ of the surveyed households borrowed, the predicted probability of credit constraints is high, at $48 \%$ (Table 6). If credit constraints are more related to the credit supply side, then the determinants of credit constraints could be more related to obstacles in the credit markets. Similarly to Crook and Hochguertel (2005), Magri (2002) and Jappelli (1990), we find that higher household income reduces the likelihood of being credit-constrained, even though all our studied households were poor.

Surprisingly, income also has a U-shaped effect on the probability of credit constraints (Figure 3) with the minimum probability at the income level of about VND 3.5 million (about US\$210). This U-shaped effect of income on credit constraints is contrary to Chen and Chivakul (2008), who found the inverted-U shape effect for credit constraint of the general population other than the poor in Bosnia and Herzegovina. All the households in our sample were poor and most of them borrowed from informal and subsidized formal credit. Extremely poor households, however, were excluded by both informal lenders and government subsidised funds. ${ }^{11}$ Therefore the higher the income per capita, the lower the credit constraints. On the other hand, households whose income per capita was higher than VND 3.5 million were more credit-constrained as income increased. As we learned previously, $96 \%$ of credit to the poor was from small credit sources (small subsidized credit and informal credit). Thus the higher credit constraints of households whose income was greater than VND 3.5 million could not be due to the exclusion by the microcredit lenders but due to higher demand for credit to finance their bigger projects, businesses or spending, however these households were lent less than what they really wanted to borrow. This group of households should be financed by larger formal credit, especially from commercial banks. These findings also suggest that if subsidized formal credit funds lend to the poor households, the credit amounts should not be fixed for all the poor but varied, based on their income levels, at least two certain amounts, one amount for households whose income is below VND 3.5 million and one amount for households whose income is above VND 3.5 million.

\footnotetext{
${ }^{11}$ According to local HEPRF officers, even if all the poor are eligible for preferred loans, they did not lend to the extremely poor because the households could not repay. They might have received direct assistance rather than credit.
} 


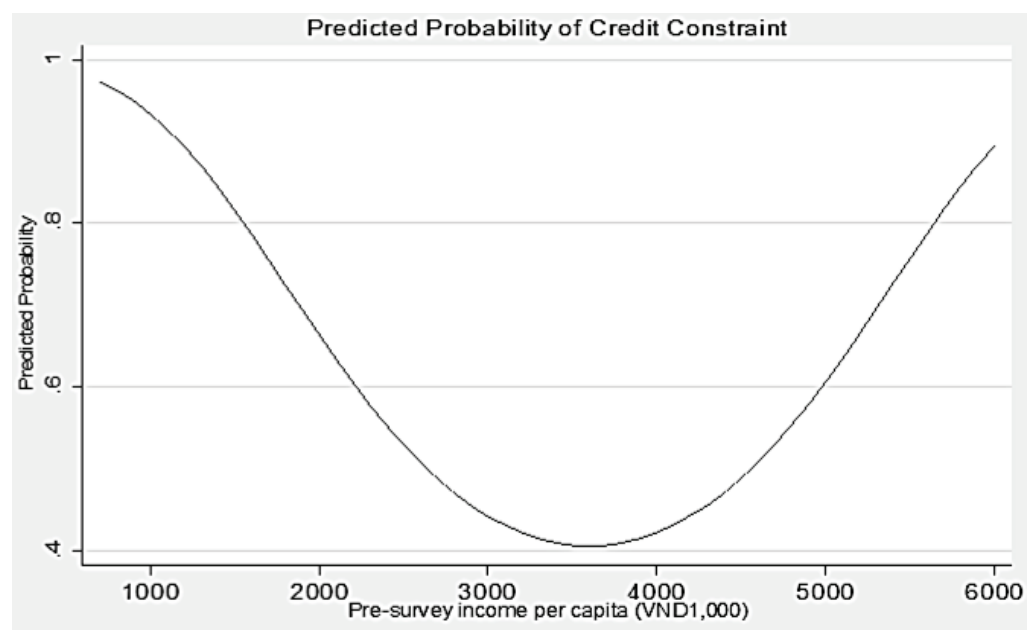

Figure 3. Predicted probabilities of credit constraints by pre-survey income per capita

In the Vietnamese context, assets such as land, house and durable fixed assets mainly represent household wealth because households usually lack investment choices for their savings due to unstable financial markets and high inflation (Barslund, Tarp, 2007). In our surveyed areas, fast industrialization and urbanization have made property more marketable and increased property values. This enables the poor to access credit easier because lenders may consider the property or fixed assets as collateral to sort out their clients. Without official documents the assets are not able to be used as collateral, but the assets may indicate potential repayment ability because the peri-urban and urban poor also have informal property transactions without legal documents since informal property markets function well in developing countries including Vietnam (Mooya, Cloete, 2007; Kim, 2004). The assets can be informally sold to repay debts, though they are not able to be lodged as collateral when borrowing, the households owning higher-valued assets are thus less likely to be credit-constrained.

Contrary to Barslund and Tarp (2007), Kedir et al, (2007), Izumida and Pham (2002), Zeller (1994) and Jappelli (1990), the credit-constrained and unconstrained poor households are homogenous in terms of household heads' gender, age, education, marital status, and household size, ${ }^{12}$ perhaps because the current study focuses on the poor other than the general population.

\footnotetext{
${ }^{12}$ We also checked with household labour force (persons aged 18-60 years old), the
} estimation result is similar to the case of household size. 
Table 6

Marginal effects on the probability of credit constraints (probit model)

\begin{tabular}{|c|c|c|c|}
\hline Explanatory variables & Model (1) & Model (2) & Model (3) \\
\hline Head's gender $($ male $=1)$ & $\begin{array}{r}0.0669 \\
(1.07) \\
\end{array}$ & $\begin{array}{r}0.0676 \\
(1.08) \\
\end{array}$ & $\begin{array}{r}0.0652 \\
(1.04) \\
\end{array}$ \\
\hline Head's age (years) & $\begin{array}{r}0.0016 \\
(0.82) \\
\end{array}$ & $\begin{array}{r}0.0016 \\
(0.83) \\
\end{array}$ & $\begin{array}{r}0.0021 \\
(1.04) \\
\end{array}$ \\
\hline Head's education (years) & $\begin{array}{r}0.0002 \\
(0.02)\end{array}$ & $\begin{array}{r}0.0006 \\
(0.07)\end{array}$ & $\begin{array}{r}0.0016 \\
(0.18)\end{array}$ \\
\hline Marital status (married $=1$ ) & $\begin{array}{r}-0.0218 \\
(0.31)\end{array}$ & $\begin{array}{r}-0.0257 \\
(0.37)\end{array}$ & $\begin{array}{r}-0.0177 \\
(0.25)\end{array}$ \\
\hline Household size in log & $\begin{array}{r}-0.0255 \\
(0.41)\end{array}$ & $\begin{array}{r}-0.0264 \\
(0.42)\end{array}$ & $\begin{array}{r}-0.0287 \\
(0.46)\end{array}$ \\
\hline Pre-survey income per capita & $\begin{array}{r}-0.0007 \\
(3.22)^{* *}\end{array}$ & $\begin{array}{r}-0.0007 \\
(3.20)^{* *}\end{array}$ & $\begin{array}{r}-0.0007 \\
(3.40)^{* *}\end{array}$ \\
\hline Pre-survey income per capita squared & $\begin{array}{l}1.01 \mathrm{e}-07 \\
(3.27)^{* *}\end{array}$ & $\begin{array}{l}1.01 \mathrm{e}-07 \\
(3.25)^{* *}\end{array}$ & $\begin{array}{l}1.03 \mathrm{e}-07 \\
(3.47)^{* *}\end{array}$ \\
\hline $\begin{array}{l}\text { Pre-survey assets in } \log \text { (acquired over } \\
24 \text { months prior to survey) }\end{array}$ & $\begin{array}{c}-0.0399 \\
(1.96)+\end{array}$ & $\begin{array}{r}-0.0407 \\
(2.00)^{*}\end{array}$ & $\begin{array}{c}-0.0344 \\
(1.67)+\end{array}$ \\
\hline Phone ownership (yes $=1$ ) & $\begin{array}{r}-0.2171 \\
(3.33)^{* *}\end{array}$ & $\begin{array}{r}-0.2158 \\
(3.30)^{* *}\end{array}$ & $\begin{array}{r}-0.2070 \\
(3.12)^{* *}\end{array}$ \\
\hline Phuoc Binh - PB (urban) & $\begin{array}{r}0.0347 \\
(0.37)\end{array}$ & & \\
\hline Long Truong - LT (rural) & $\begin{array}{r}-0.0012 \\
(0.01)\end{array}$ & & \\
\hline Long Phuoc - LP (rural) & $\begin{array}{r}-0.0978 \\
(1.28)\end{array}$ & & \\
\hline \multicolumn{4}{|l|}{ Interaction terms } \\
\hline Borrowing neighbour proportion $\mathrm{x}$ TNPA & & $\begin{array}{l}0.2815 \\
(0.73)\end{array}$ & \\
\hline Borrowing neighbour proportion $\mathrm{x} P \mathrm{~B}$ & & $\begin{array}{l}0.3216 \\
(0.89)\end{array}$ & \\
\hline Borrowing neighbour proportion $\mathrm{x}$ LT & & $\begin{array}{l}0.2406 \\
(0.76) \\
\end{array}$ & \\
\hline Borrowing neighbour proportion $\mathrm{x}$ LP & & $\begin{array}{l}0.1234 \\
(0.39) \\
\end{array}$ & \\
\hline Distance to nearest bank $(\mathrm{km}) \times \mathrm{TNPA}$ & & & $\begin{array}{l}0.1813 \\
(1.78)+ \\
\end{array}$ \\
\hline Distance to nearest bank $(\mathrm{km}) \times \mathrm{PB}$ & & & $\begin{array}{l}0.3732 \\
(2.09)^{*}\end{array}$ \\
\hline Distance to nearest bank $(\mathrm{km}) \times \mathrm{LT}$ & & & $\begin{array}{l}0.1685 \\
(2.30)^{*}\end{array}$ \\
\hline Distance to nearest bank $(\mathrm{km}) \times \mathrm{LP}$ & & & $\begin{array}{l}0.0115 \\
(0.61) \\
\end{array}$ \\
\hline Wald $\chi^{2}$ test & $34.99 * *$ & $34.33 * *$ & $40.40^{* *}$ \\
\hline Prob $>\chi^{2}$ & 0.0005 & 0.0011 & 0.0001 \\
\hline Predicted probability & 0.4790 & 0.4790 & 0.4790 \\
\hline Pseudo $\mathrm{R}^{2}$ & 0.0700 & 0.0700 & 0.0800 \\
\hline Observations & 411 & 411 & 411 \\
\hline
\end{tabular}

Notes: Robust $\mathrm{z}$ statistics in parentheses; statistically significant at $10 \%(+)$, at $5 \%\left({ }^{*}\right)$, and at $1 \%(* *)$.Tang Nhon PhuA (TNPA) is set as a reference ward. 
Finally, households dwelling far from banks within each ward had a higher probability of being credit-constrained. The effect of the distance to the nearest bank is significant for the TNPA, PB, and LT wards, but not for the LP ward (Table 6, Model 3) where in a purely rural area the distance does not obstruct the poor households from credit resources. Better community, relatives, neighbouring relationships and interpersonal trust may help households in this pure rural ward to have not only a higher probability of credit participation, especially credit from the informal sector, but also lower the likelihood of being credit-constrained (Table 6). This suggests that community mutual help systems through credit could be a good channel of consumption smoothing including healthcare and children's schooling. On the other hand, with weaker community relationships in more urban wards, poor households find it hard to borrow and are highly credit-constrained. Subsidized funds which are limited are usually the last resort of the poor in the urban areas.

\section{CONCLUSION AND POLICY IMPLICATIONS}

This paper examinesthe factors affecting credit participation and credit constraints in peri-urban areas in Vietnam and finds that: first, the presence of many commercial banks does not help the poor access to formal credit, and hence the poor in the peri-urban areas rely heavily upon informal credit. Unlike the credit uses in rural Vietnam, credits in the peri-urban areas are mainly used for consumption. Second, households in rural wards have a higher probability of borrowing than their counterparts in the more urban wards thanks to better social relationships in rural areas. Moreover, competition from neighbouring borrowers adversely affects the propensity of borrowing in urban areas (wards) where the poor are more reliant upon government subsidised credit funds, which are limited.

Third, a closer look at specified microcredit sources reveals that the roles of marital status, communication facilities, dwelling places, and competition from neighbours vary across different credit market segments. Married-head households tend to avoid informal credit, whereas the better-communicating households borrow more from formal credit lenders. Households located far from banks in more rural areas were unable to borrow from the formal credit resources, but these households were more likely to borrow from informal credit. Moreover, the competition among households exists only in formal credit markets which provide mostly subsidized credit loans. 
Finally, asset-wealthier households and phone ownership amongst the poor group appear to be less credit-constrained. The likelihood of both credit participation and credit constraints increases with distance to the nearest banks, which implies that households living far out were able to borrow but their borrowed amounts were lower than their optimal amounts since they mainly borrowed from informal (and also small) credit. This suggests that supply-side intervention could help overcome credit constraints. Overall, the poor in urban wards are slightly more credit-constrained due to exclusion by commercial banks, and by informal credit presumably due to weak community relationships and interpersonal trust.

There remain some caveats in this study. The determinants of credit participation and constraints would come from unobservable attributes such as households' entrepreneurial ability, attitude to risk and access to social networks, which are assumed to be associated with pre-survey incomes and assets in this study. Further advances on the current research should control for these attributes by employing fixed effects methods with panel data to consolidate the findings in this paper.

\section{REFERENCES}

Allcott, H., Karlan, D., Möbius, M. M., Rosenblat, T. S., Szeidl, A., Community Size and Network Closure, "The American Economic Review", 97(2), pp. 80-85, 2007.

Armendariz, A., Morduch, J., The Economics of Microfinance ( $2^{\text {nd }}$ eds). The MIT Press, Cambridge, Massachusetts, 2010.

Banerjee, A., Duflo, E., Giving Credit Where It Is Due, "Journal of Economic Perspectives", 24(3), pp. 61-80, 2010.

Barslund, M., Tarp, F., Formal and Informal Rural Credit in Four Provinces of Vietnam, "Journal of Development Studies", 44(4), pp. 485-503, 2007.

Chen, K., Chivakul, M., What Drives Household Borrowing and Credit Constraints? Evidence from Bosnia and Herzegovina (IMF Working Paper WP/08/202). International Monetary Fund, Washington DC, 2008.

Conning, J., Udry, C., Rural Financial Markets in Developing Countries (Discussion Paper No. 914). Yale University, Economic Growth Center, 2005.

Crook, J., The Demand for Household Debt in the USA: Evidence from the 1995 Survey of Consumer Finance, "Applied Financial Economics”, 11, pp. 83-91, 2001.

Crook, J., Hochguertel, S., Household Debt and Credit Constraints: Evidence from OECD Countries (Working Paper Series No 05/02). University of Edinburgh, Credit Research Center, 2005.

Crook, J., Hochguertel, S., US and European Household Debt and Credit Constraints (Tinbergen Institute Discussion Paper No. 2007-087/3). Retrieved from http://www.tinbergen.nl/discussionpapers/07087.pdf, 2007. 
Debertin, D. (n.d.). A Comparison of Social Capital in Rural and Urban Settings. Retrieved from University of Kentucky, Department of Agricultural Economics website: http://www.uky.edu/ deberti/socsaea.htm

Del-Rio, A., Young, G., The Determinants of Uncensored Borrowing: Evidence from the British Household Panel Survey (Working Paper No. 263). Bank of England, 2005.

Diagne, A., Determinants of Household Access to and Pparticipation in Formal and Informal Credit Markets in Malawi (FCND Discussion Paper No.67). International Food Policy Research Institute (IFPRI), Washington, DC, 1999.

Diagne, A., Zeller, M., Sharma, M., Empirical Measurements of Households' Access to Credit and Credit Constraints in Developing Countries: Methodological Iissues and Evidence. Retrieved from International Food Policy Research Institute (IFPRI) website: http://www.ifpri.org/sites/default/files/publications/fcnbr90.pdf, 2000.

Doan, T.,Gibson, J. Return to Education in Vietnam during the Recent Transformation, "International Journal of Education Economics and Development", 3(4), pp. 314-329, 2012.

Fallon, P., Lucas, R., The Impact of Financial Crises on Labor Markets, Household Incomes and Poverty: A Review of Evidence, "The Work Bank Research Observers", 17(2), pp. 21-45, 2002.

Hofferth, S. L., Iceland, J., Social Capital in Rural and Urban Communities, Rural Sociology Society. December, 1998.

IFC, Vietnam Financial Sector Diagnostic. World Bank Group, International Financial Corporation, 2006.

Izumida, Y., Pham, B. D., Rural Development Finance in Vietnam: An Econometric Analysis of Household Surveys. World Development, 30(2), pp. 319-335, 2002.

Jappelli, T., Who Is Credit Constrained in the US Economy?, "The Quarterly Journal of Economics", 105(1), 1990.

Johnston, D., Morduch, J., Microcredit vs. Microsaving: Evidence from Indonesia. Retrieved from http://siteresources.worldbank.org/INTFR/Resources/Microcredit_versus_Microsaving_Evidence_from_Indonesia.pdf, 2007.

Johnston, J., Dinardo, J., Econometric Methods. The McGraw-Hill Companies, Inc., New York, 1997.

Kedir, A., Ibrahim, G., Torres, S., Household-level Credit Constraints in Urban Ethiopia. Retrieved from http://economia.ucu.edu.uy/attachments/026_Credit\%20Constraints\% 20JAE_2009t.pdf, 2007.

Khandker, S., Microfinance and Poverty: Evidence Using Panel Data from Bangladesh. "The World Bank Economic Review”, 19(2), pp. 263-286, 2005.

Kim, A., A Market without the 'Right' Property Rights, "Economics of Transition", 12(2), pp. 275-305, 2004.

Kochar, A., Explaining Household Vulnerability to Idiosyncratic Income Shocks, "American Economic Review", 85(2), pp. 159-1964, 1995.

Kochar, A., Smoothing Consumption by Smoothing Income: Hours-of-work Responses to Idiosyncratic Agricultural Shocks in Rural India, "Review of Economics and Statistics", 81(1), pp. 50-61, 1999. 
McKenzie, D., Aggregate Shocks and Urban Labor Market Responses: Evidence from Argentina's Financial Crisis, "Economic Development and Cultural Change", 52(4), pp. 719-758, 2004.

Nguyen, V. C., Determinants of Credit Participation and Its Impact on Household Cconsumption: Evidence from Rural Vietnam. Paper presented at the $3^{\text {rd }}$ Leicester $\mathrm{PhD}$ Conference on Economics, England, May 2007.

Rashid, S., The Urban Poor in Dhaka City: Their Struggles and Coping Strategies During the Floods of 1998, "Disasters", 24(3), pp. 240-253, 2000.

Schreiner, M., Nagarajan, G., Predicting Credit Worthiness with Publicly Observable Characteristics: Evidence from ASCRAs and RoSCAs in the Gambia, "Savings and Development", 22(4), pp. 399-414, 1998.

Skoufias, E., Economic Crises and Natural Disasters: Coping Strategies and Policy Implications, "World Development", 31(7), pp. 1087-1102, 2003.

Swain, R. B., The Demand and Supply of Credit for Households, "Applied Economics", 39, pp. 2681-92, 2007.

VDR, Vietnam Development Report 2004 (Joint Donor Report to the Vietnam consultative Group Meeting in December 2003). Hanoi, Vietnam, 2004.

Verbeek, M., A Guide to Modern Econometrics. Southern Gate, Chichester, West Sussex, England Hoboken, NJ: John Wiley \& Sons, 2004.

Zeller, M., Determinants of Credit Rationing: A Study of Informal Lenders and Formal Credit Groups in Madagascar. "World Development", 22(12), pp. 1895-1907, 1994.

Received: March 2014, revised: January 2015

Acknowledgments: We thank Andrea Menclova (Canterbury University) and Asadul Islam (Monash University) for their significant comments and suggestions to improve the paper, and participants, especially Valerie Kozel (the World Bank), of the Workshop on Development in the Mekong region at the University of Waikato for their helpful comments. Any remaining errors in the paper are those of the authors. We thank Vietnam National University, Hanoi and VNU University of Economics and Business for funding the publication of this paper. 